\title{
STUDI DAYA DUKUNG LATERAL FONDASI TIANG FREE-HEAD MENGGUNAKAN PROGRAM BUATAN BERBAHASA FORCE FORTRAN 2.0
}

\author{
Lilya $^{1}$ dan Gregorius Sandjaja $S^{2}$ \\ ${ }^{1}$ Program Studi Sarjana Teknik Sipil, Universitas Tarumanagara, Jl. Letjen S. Parman No.1 Jakarta \\ Email: lilya.lyla@gmail.com \\ ${ }^{2}$ Program Studi Sarjana Teknik Sipil, Universitas Tarumanagara, Jl. Letjen S. Parman No.1 Jakarta \\ Email:gregorius@ft.untar.ac.id
}

\begin{abstract}
ABSTRAK
Fondasi merupakan bagian paling bawah dari suatu konstruksi yang penting untuk memikul beban bangunan di atasnya sehingga didesain dengan baik agar dapat menahan beban-beban yang bekerja, salah satunya adalah beban lateral. Analisis lateral telah dilakukan dengan beberapa metode. Dalam analisis ini metode yang digunakan antara lain metode Broms, Matlock \& Reese, dan metode beda hingga. Ada 2 jenis tanah yang homogen, yaitu tanah kohesif dan non-kohesif. Metode-metode yang digunakan dalam analisis memberikan hasil yang berbeda sehingga menunjukkan kelebihan dan kekurangan pada masing-masing metode yang mempengaruhi ketelitian hasil analisis. Ketelitian hasil analisis ini dipengaruhi oleh parameter tanah yang digunakan yaitu ketelitian hasil akan meningkat seiring dengan kedetailan parameter tanah yang digunakan dalam analisis.
\end{abstract}

Kata kunci: metode Broms, metode Matlock \& Reese, metode beda hingga, parameter tanah.

\section{PENDAHULUAN}

Fondasi merupakan bagian paling bawah dari suatu konstruksi yang penting untuk memikul beban bangunan di atasnya (Napitupulu dan Iskandar, 2013). Fondasi harus didesain dengan baik agar dapat menopang bangunan dan meneruskan beban bangunan termasuk beban luar ke lapisan tanah di bawahnya. Fondasi yang baik harus dapat menahan beban-beban yang bekerja pada fondasi. Salah satu beban yang perlu diperhitungkan pada perencanaan fondasi adalah beban lateral. Terdapat banyak metode perhitungan untuk analisis daya dukung lateral fondasi tiang seperti metode Broms dan metode Matlock \& Reese. Program aplikasi untuk menghitung daya dukung lateral fondasi tiang sudah banyak tersedia tetapi membutuhkan biaya mahal, sehingga program ini dibuat sebagai alternatif untuk melakukan perhitungan daya dukung lateral fondasi tiang dengan biaya yang lebih murah.

Dalam makalah ini akan disajikan program yang dibuat sendiri dengan bahasa Force FORTRAN 2.0 khusus untuk menghitung dan menganalisis daya dukung lateral fondasi tiang berdasarkan metode beda hingga (finite-difference method). Dalam pembuatan program ini ada beberapa hal yang membatasi, yaitu: jenis tanah berupa kohesif dan non-kohesif, tanah bersifat homogen, dan parameter yang digunakan diambil berdasarkan nilai rata-rata data tanah. Dalam memodelkan fondasi tiang pada program, jumlah elemen dibatasi maksimum sepuluh elemen.

Hasil analisis dengan program berbahasa Force FORTRAN 2.0 kemudian dibandingkan dengan hasil perhitungan menggunakaan metode yang diusulkan oleh Broms dan Matlock \& Reese.

\section{LANDASAN TEORI}

\section{Faktor Kekakuan Gaya Lateral Fondasi Tiang}

Menurut Tomlinson dan Woodward (2015) untuk menentukan besar factor kekakuan fondasi tiang yang mendukung beban lateral, perlu diketahui faktor kekakuan fondasi tiang, $\mathrm{R}$ dan $\mathrm{T}$.

$$
\begin{aligned}
& \mathrm{R}=\sqrt[4]{\frac{E_{p} I_{p}}{k_{h} B}} \\
& \mathrm{~T}=\sqrt[5]{\frac{E_{p} I_{p}}{n_{h}}}
\end{aligned}
$$


dengan, $\mathrm{R}$ = faktor kekakuan fondasi tiang untuk tanah konstan, $\mathrm{E}_{\mathrm{p}}=$ modulus elastis fondasi tiang, $\mathrm{I}_{\mathrm{p}}=$ momen inersia fondasi tiang, $\mathrm{k}_{\mathrm{h}}=$ modulus subgrade tanah horizontal, $\mathrm{B}=$ ukuran fondasi tiang, $\mathrm{T}=$ faktor kekakuan fondasi tiang untuk tanah yang tidak konstan, $\mathrm{n}_{\mathrm{h}}=$ koefisien variasi modulus tanah.

Nilai $\mathrm{n}_{\mathrm{h}}$ mempunyai hubungan dengan modulus subgrade horizontal sebagai berikut:

$$
\mathrm{k}_{\mathrm{h}}=n_{h} \times \frac{x}{B}
$$

dengan, $\mathrm{x}=$ kedalaman yang ditinjau, $\mathrm{n}_{\mathrm{h}}=350 \sim 700 \mathrm{kN} / \mathrm{m}^{3}$ untuk tanah lempung lunak yang terkonsolidasi normal, $\mathrm{n}_{\mathrm{h}}=150 \mathrm{kN} / \mathrm{m}^{3}$ untuk tanah lanau organik lunak.

\section{Metode Broms}

Metode perhitungan ini menggunakan diagram tekanan tanah yang disederhanakan dengan menganggap bahwa sepanjang kedalaman fondasi tiang reaksi atau tahanan tanah mencapai nilai ultimate.

Pada kondisi fondasi tiang pendek free-head pada tanah kohesif, momen maksimum diberikan untuk dua rentang kedalaman.

$$
\begin{gathered}
\mathrm{M}_{\max }=H_{u}\left(e+1,5 B+0,5 x_{o}\right) \text { untuk } 1,5 \mathrm{~B}+\mathrm{x}_{\mathrm{o}} \\
\mathrm{M}_{\max }=2,25 B c_{u}\left(L-x_{o}\right)^{2} \text { untuk L - } \mathrm{x}_{0} \\
\mathrm{x}_{\mathrm{o}}=\frac{H_{u}}{9 c_{u} B}
\end{gathered}
$$

dengan, $\mathrm{M}_{\max }=$ momen maksimum, $\mathrm{H}_{\mathrm{u}}$ = gaya lateral, $\mathrm{e}=$ jarak ujung fondasi tiang ke permukaan tanah, $\mathrm{x}_{\mathrm{o}}=$ letak momen maksimum terjadi, $\mathrm{c}_{\mathrm{u}}=$ undrained shear strength, $\mathrm{L}=$ panjang fondasi tiang.

Pada kondisi fondasi tiang pendek free-head pada tanah non-kohesif, momen maksimum pada kedalaman $\mathrm{x}_{0}$ sebesar:

$$
\begin{gathered}
\mathrm{M}_{\max }=H_{u}\left(e+1,5 x_{o}\right) \\
\mathrm{x}_{\mathrm{o}}=0,82 \frac{H_{u}}{\gamma^{\prime} B K_{p}}
\end{gathered}
$$

dengan, $\gamma^{\prime}=$ tegangan efektif tanah, $\mathrm{K}_{\mathrm{p}}=$ koefisien tekanan tanah pasif.

Pada kondisi fondasi tiang panjang free-head pada tanah kohesif, momen maksimum pada kedalaman $\mathrm{x}_{0}$ sebesar:

$$
\mathrm{M}_{\max }=H_{u}\left(e+1,5 B+x_{o}\right)-0,5 x_{o}\left(9 c_{u} B x_{o}\right)
$$

dengan, $\mathrm{x}_{0}$ sesuai pada persamaan (6).

Pada kondisi fondasi tiang panjang free-head pada tanah non-kohesif, momen maksimum pada kedalaman $\mathrm{x}_{0}$ sebesar:

$$
\begin{gathered}
\mathrm{M}_{\text {max }}=H_{u}\left(e+0,67 x_{o}\right) \\
\mathrm{x}_{\mathrm{o}}=0,82\left(\frac{H_{u}}{\gamma^{\prime} B K_{p}}\right)^{0,5}
\end{gathered}
$$

Pada tanah kohesif, besar defleksi dikaitkan dengan faktor tak berdimensi $\beta$ L.

$$
\beta=\left(\frac{k_{h} B}{4 E_{p} I_{p}}\right)^{1 / 4}
$$

Sehingga, $\beta \mathrm{L}<1,5$ untuk fondasi tiang pendek free-head, defleksi dan putaran sudut sebesar:

$$
y_{o}=\frac{4 H_{u}(1+1,5 e / L)}{k_{h} B L}
$$




$$
\theta=\frac{6 H_{u}(1+2 e / L)}{k_{h} B L^{2}}
$$

$\beta \mathrm{L}>2,5$ untuk fondasi tiang panjang free-head, defleksi dan putaran sudut sebesar:

$$
\begin{aligned}
y_{o} & =\frac{4 H_{u} \beta(e \beta+1)}{k_{h} B} \\
\theta & =\frac{2 H_{u} \beta^{2}(1+2 e \beta)}{k_{h} B}
\end{aligned}
$$

Pada tanah non-kohesif, besar defleksi dikaitkan dengan faktor tak berdimensi $\alpha \mathrm{L}$.

$$
\alpha=\left(\frac{n_{h}}{E_{p} I_{p}}\right)^{1 / 5}
$$

Sehingga, $\alpha \mathrm{L}<2$ untuk fondasi tiang pendek free-head, defleksi dan putaran sudut sebesar:

$$
\begin{gathered}
y_{o}=\frac{18 H_{u}(1+1,33 e / L)}{L^{2} n_{h}} \\
\theta=\frac{24 H_{u}(1+1,5 e / L)}{L^{3} n_{h}}
\end{gathered}
$$

$\alpha \mathrm{L}>4$ untuk fondasi tiang panjang free-head, defleksi dan putaran sudut sebesar:

$$
\begin{gathered}
y_{o}=\frac{2,4 H_{u}}{\left(n_{h}\right)^{3 / 5}\left(E_{p} I_{p}\right)^{2 / 5}}+\frac{1,6 H_{u} e}{\left(n_{h}\right)^{2 / 5}\left(E_{p} I_{p}\right)^{3 / 5}} \\
\theta=\frac{1,6 H_{u}}{\left(n_{h}\right)^{2 / 5}\left(E_{p} I_{p}\right)^{3 / 5}}+\frac{1,74 H_{u} e}{\left(n_{h}\right)^{1 / 5}\left(E_{p} I_{p}\right)^{4 / 5}}
\end{gathered}
$$

\section{Metode Matlock \& Reese (Tomlinson dan Woodward, 2015)}

Metode ini merupakan metode yang menggunakan pendekatan analisis berdasarkan reaksi subgrade dari tanah. Berikut persamaan-persamaan untuk menghitung defleksi $\left(\mathrm{y}_{\mathrm{x}}\right)$, momen $\left(\mathrm{M}_{\mathrm{x}}\right)$, putaran sudut atau slope $\left(\mathrm{S}_{\mathrm{x}}\right)$, gaya geser $\left(\mathrm{V}_{\mathrm{x}}\right)$, dan reaksi tanah $\left(\mathrm{P}_{\mathrm{x}}\right)$ :

$$
y_{x}=y_{A}+y_{B}=A_{y} \frac{H T^{3}}{E_{p} I_{p}}+B_{y} \frac{M T^{2}}{E_{p} I_{p}}
$$

dengan, $\mathrm{y}_{\mathrm{x}}=$ defleksi, $\mathrm{y}_{\mathrm{A}}=$ defleksi atas, $\mathrm{y}_{\mathrm{B}}=$ defleksi bawah, $\mathrm{H}=$ gaya lateral, $\mathrm{M}=$ momen, $\mathrm{A}_{\mathrm{y}}=$ koefisien atas untuk defleksi, $\mathrm{B}_{\mathrm{y}}=$ koefisien bawah untuk defleksi.

$$
S_{x}=S_{A}+S_{B}=A_{s} \frac{H T^{2}}{E_{p} I_{p}}+B_{s} \frac{M T}{E_{p} I_{p}}
$$

dengan, $\mathrm{S}_{\mathrm{x}}=$ putaran sudut, $\mathrm{S}_{\mathrm{A}}=$ putaran sudut atas, $\mathrm{S}_{\mathrm{B}}=$ putaran sudut atas, $\mathrm{A}_{\mathrm{s}}=$ koefisien atas untuk putaran sudut, $\mathrm{B}_{\mathrm{s}}=$ koefisien bawah untuk putaran sudut.

$$
M_{x}=M_{A}+M_{B}=A_{m} H T+B_{m} M
$$

dengan, $\mathrm{M}_{\mathrm{x}}=$ momen, $\mathrm{M}_{\mathrm{A}}=$ momen atas, $\mathrm{M}_{\mathrm{B}}=$ momen atas, $\mathrm{A}_{\mathrm{m}}=$ koefisien atas untuk momen, $\mathrm{B}_{\mathrm{m}}=$ koefisien bawah untuk momen.

$$
V_{x}=V_{A}+V_{B}=A_{v} H+B_{v} \frac{M}{T}
$$

dengan, $V_{x}=$ gaya geser, $V_{A}=$ gaya geser atas, $V_{B}=$ gaya geser atas, $A_{v}=$ koefisien atas untuk gaya geser, $B_{v}=$ koefisien bawah untuk gaya geser. 


$$
P_{x}=P_{A}+P_{B}=A_{p} \frac{H}{T}+B_{p} \frac{M}{T^{2}}
$$

dengan, $\mathrm{P}_{\mathrm{x}}=$ reaksi tanah, $\mathrm{P}_{\mathrm{A}}=$ reaksi tanah atas, $\mathrm{P}_{\mathrm{B}}=$ reaksi tanah atas, $\mathrm{A}_{\mathrm{p}}=$ koefisien atas untuk reaksi tanah, $\mathrm{B}_{\mathrm{p}}=$ koefisien bawah untuk reaksi tanah.

Nilai-nilai koefisien A dan B pada persamaan (22) sampai dengan persamaan (26) disediakan dalam bentuk grafik yang ada pada dilihat pada banyak literatur antara lain Tomlinson dan Woodward (2015).

\section{Metode Beda Hingga (Finite-Difference Method)}

Menurut analisis Sujatmiko (2011) dan konsep fondasi WINKLER, fondasi tiang pancang dapat diidealisasikan sebagai sebuah balok sepanjang sumbu $\mathrm{x}$ dengan penampang yang konstan di sepanjang balok. Pada ujung fondasi tiang diberi beban lateral (P) pada arah sumbu y dan reaksi tanah diidealisasikan sebagai titik-titik pegas yang bekerja di sepanjang balok fondasi tiang pancang. Berikut ini contoh permodelan dengan fondasi tiang yang dibagi menjadi 5 node:

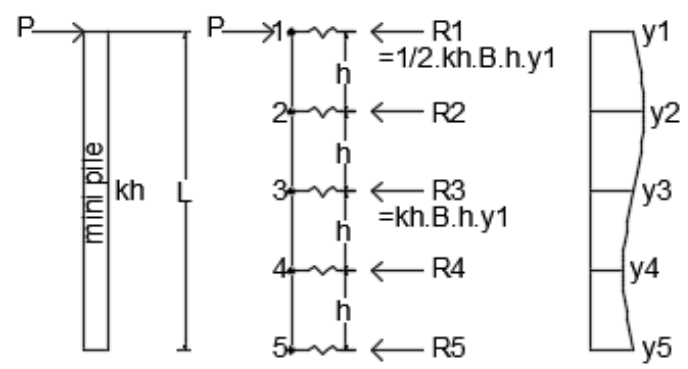

Gambar 1. Model Permasalahan (Sujatmiko, 2011)

Sehingga dengan menggunakan formulasi beda hingga diferensial orde 2, maka akan didapat persamaan-persamaan berikut:

$$
\begin{gathered}
\frac{E_{p} I_{p}}{h^{2}}\left(y_{n-1}-2 y_{n}+y_{n+1}\right)=-M \\
\frac{E_{p} I_{p}}{h^{2}}=C \\
C\left(y_{n-1}-2 y_{n}+y_{n+1}\right)=-M
\end{gathered}
$$

dengan, $\mathrm{y}_{\mathrm{n}}=$ defleksi pada tiap node, $\mathrm{h}=$ jarak antar elemen.

Adapun reaksi tanah di sepanjang balok fondasi tiang pancang pada node beda hingga adalah sebagai berikut:

$$
\begin{gathered}
R_{1}=\frac{1}{2} k_{h} \text { Bhy }_{1} \\
R_{2} \text { sampai }_{4}=k_{h} \text { Bhy }_{i} \\
R_{5}=\frac{1}{2} k_{h} \text { Bhy }_{5}
\end{gathered}
$$

dengan, $\mathrm{R}_{\mathrm{i}}=$ reaksi tanah pada tiap node, $\mathrm{y}_{\mathrm{i}}=$ defleksi pada tiap node.

Berdasarkan keseimbangan gaya didapat:

Node $2, \Sigma \mathrm{M}_{2}=0$

$$
C\left(y_{1}-2 y_{2}+y_{3}\right)+R_{1} h-P h=0
$$

Node $3, \Sigma \mathrm{M}_{3}=0$

$$
C\left(y_{2}-2 y_{3}+y_{4}\right)+R_{1} 2 h+R_{2} h-P 2 h=0
$$

Node $4, \Sigma \mathrm{M}_{4}=0$ 


$$
C\left(y_{3}-2 y_{4}+y_{5}\right)+R_{1} 3 h+R_{2} 2 h+R_{3} h-P 3 h=0
$$

Node $5, \Sigma \mathrm{M}_{5}=0$

$$
R_{1} 4 h+R_{2} 3 h+R_{3} 2 h+R_{4} h-P 4 h=0
$$

$\Sigma \mathrm{F}=0$

$$
R_{1}+R_{2}+R_{3}+R_{4}+R_{5}-P=0
$$

dengan, $\mathrm{P}$ = gaya lateral.

Sehingga dengan menggunakan persamaan-persamaan keseimbangan gaya tersebut dapat dihitung besar defleksi yang terjadi dengan menggunakan metode matriks sebagai berikut:

$$
[A] \times\left\{y_{i}\right\}=\{B\}
$$

dengan, $[\mathrm{A}]=$ matriks konstanta defleksi, $\left\{\mathrm{y}_{\mathrm{i}}\right\}=$ vektor defleksi pada tiap node, $\{\mathrm{B}\}=$ vektor konstanta persamaan.

\section{METODOLOGI PENELITIAN}

\section{Diagram Alir Penelitian}

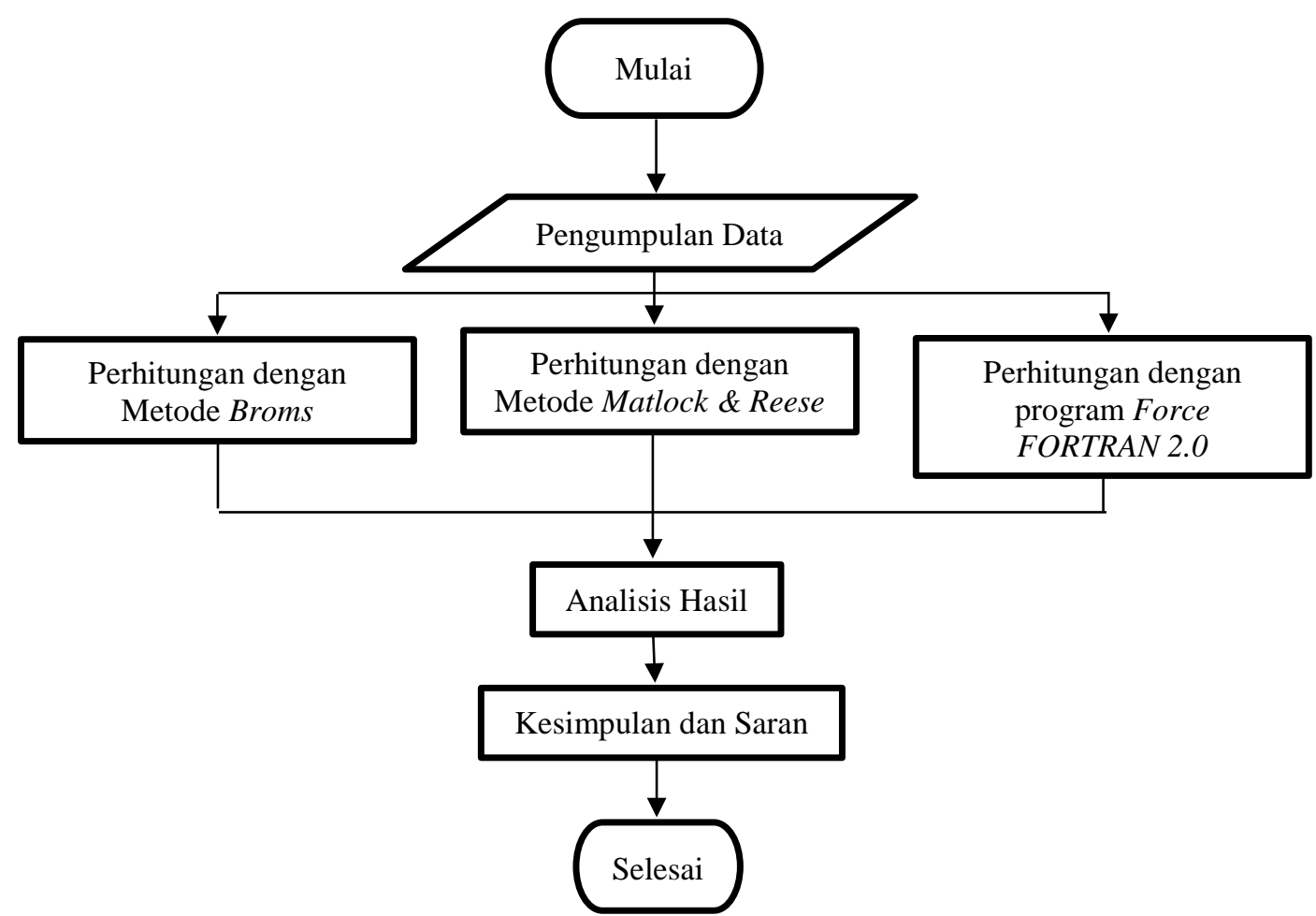

Gambar 2. Diagram Alir Penelitian

\section{HASIL PENELITIAN DAN PEMBAHASAN}

\section{Program Perhitungan Daya Dukung Lateral Berbahasa Force FORTRAN 2.0}

Program untuk menghitung gaya lateral fondasi tiang free-head dibuat dengan menggunakan rumus-rumus metode beda hingga seperti yang tercantum pada persamaan (27) sampai dengan (38). Parameter tanah yang dimasukkan ke dalam perhitungan yaitu: bentuk fondasi tiang, ukuran fondasi tiang, mutu bahan, panjang fondasi tiang, modulus subgrade tanah, dan jumlah elemen fondasi tiang. Hasil dari perhitungan program berupa nilai momen di tiap elemen, defleksi yang terjadi pada tiap elemen, dan besar gaya lateral fondasi tiang. 


\section{Studi Kasus Penggunaan Program}

Dalam studi kasus penggunaan program ini akan dilakukan pada fondasi bangunan 16 lantai dengan semibasement pada tanah kohesif yang memiliki kedalaman 19 m, sedangkan pada tanah non-kohesif digunakan data tanah untuk pembuatan turap dan fondasi tiang dipancang hingga kedalaman $23 \mathrm{~m}$. Spesifikasi masing-masing fondasi tiang free-head pada kedua jenis tanah tersebut adalah berbentuk persegi berukuran 45 x $45 \mathrm{~cm}^{2}$ dengan mutu K450 dan defleksi ijin $12 \mathrm{~mm}$. Sebelum dilakukan perhitungan dengan program, dilakukan perhitungan dengan metode Broms dan Matlock \& Reese. Hasil perhitungan tersebut akan dibandingkan dengan hasil perhitungan menggunakan program berbahasa Force FORTRAN 2.0.

\section{Analisis dengan Metode Broms}

Parameter yang digunakan dalam perhitungan ini merupakan data rata-rata sepanjang fondasi seperti yang tercantum pada tabel berikut:

Tabel 1. Parameter pada tanah kohesif

\begin{tabular}{lll}
\hline Modulus elastis fondasi tiang $\left(\mathrm{E}_{\mathrm{p}}\right)$ & \multicolumn{2}{l}{$28723883,7903 \mathrm{kN} / \mathrm{m}^{2}$} \\
\hline Momen inersia fondasi tiang $\left(\mathrm{I}_{\mathrm{p}}\right)$ & 0,003417188 & $\mathrm{~m}^{4}$ \\
\hline Modulus subgrade tanah $\left(\mathrm{k}_{\mathrm{h}}\right)$ & 12833,3333 & $\mathrm{kN} / \mathrm{m}^{3}$ \\
\hline Undrained shear strength $\left(\mathrm{c}_{\mathrm{u}}\right)$ & 70 & $\mathrm{kN} / \mathrm{m}^{2}$ \\
\hline
\end{tabular}

Tabel 2. Parameter pada tanah non-kohesif

\begin{tabular}{lll}
\hline Modulus elastis fondasi tiang $\left(\mathrm{E}_{\mathrm{p}}\right)$ & \multicolumn{2}{l}{$28723883,7903 \mathrm{kN} / \mathrm{m}^{2}$} \\
\hline Momen inersia fondasi tiang $\left(\mathrm{I}_{\mathrm{p}}\right)$ & 0,003417188 & $\mathrm{~m}^{4}$ \\
\hline Koefisien variasi modulus tanah $\left(\mathrm{n}_{\mathrm{h}}\right)$ & 1333,3333 & $\mathrm{kN} / \mathrm{m}^{3}$ \\
\hline Tegangan efektik tanah $(\gamma)$ & 15 & $\mathrm{kN} / \mathrm{m}^{3}$ \\
\hline Koefisien tekanan tanah pasif $\left(\mathrm{K}_{\mathrm{p}}\right)$ & 0,1024 & \\
\hline
\end{tabular}

Sehingga dapat dihitung besar gaya lateral, putaran sudut, dan momennya berdasarkan besar defleksi ijinnya dengan menggunakan persamaan (6), (9) sampai dengan (12), (15) sampai dengan (17), (20), dan (21). Pada tanah kohesif di kedalaman 0 sampai 8 meter merupakan tanah lunak dan sekitar setengahnya digunakan untuk semibasemet sehingga kedalaman tersebut dapat diabaikan sehingga didapat e $=8 \mathrm{~m}$ dan $\mathrm{L}=11 \mathrm{~m}$. Berikut hasil perhitungan yang didapat:

Tabel 3. Hasil analisis

\begin{tabular}{lllll} 
& & Tanah Kohesif & \multicolumn{2}{c}{ Tanah Non-Kohesif } \\
\cline { 2 - 5 } Faktor tak berdimensi & 3,8331 & (fondasi tiang panjang) & 9,7359 & (fondasi tiang panjang) \\
\hline Gaya lateral $(\mathrm{H})$ & 13,14 & $\mathrm{kN}$ & 37,2133 & $\mathrm{kN}$ \\
\hline Putaran sudut $(\theta)$ & 0,0036 & $\mathrm{rad}$ & $0,00339 \mathrm{rad}$ \\
\hline Letak momen maksimum $\left(\mathrm{x}_{\mathrm{o}}\right)$ & 0,0463 & $\mathrm{~m}$ & 6,0160 & $\mathrm{~m}$ \\
\hline Momen maksimum $\left(\mathrm{M}_{\max }\right)$ & $113,9893 \mathrm{kNm}$ & $149,9958 \mathrm{kNm}$ \\
\hline
\end{tabular}




\section{Analisis dengan Metode Matlock \& Reese}

Parameter yang digunakan dalam perhitungan merupakan data tanah berdasarkan tiap lapisannya seperti yang tercantum pada Tabel berikut:

Tabel 4. Parameter analisis pada tanah kohesif

\begin{tabular}{ccccccc}
\hline $\mathrm{x}(\mathrm{m})$ & $\mathrm{n}_{\mathrm{h}}\left(\mathrm{kN} / \mathrm{m}^{3}\right)$ & $\mathrm{k}_{\mathrm{h}}\left(\mathrm{kN} / \mathrm{m}^{3}\right)$ & $\mathrm{T}$ & $\mathrm{Z}$ & Zmaks & $\mathrm{e}(\mathrm{m})$ \\
\hline 1,5 & 350 & 1166,6667 & 2,4266 & 0,6182 & 4,5331 & 8 \\
\hline 3,0 & 350 & 2333,3333 & 2,1125 & 1,4201 & 5,2072 & 8 \\
\hline 4,5 & 350 & 3500 & 1,9479 & 2,3102 & 5,6471 & 8 \\
\hline 6,0 & 350 & 4666,6667 & 1,8390 & 3,2626 & 5,9815 & 8 \\
\hline 7,5 & 350 & 5833,3333 & 1,7587 & 4,2644 & 6,2545 & 8 \\
\hline 9,0 & 350 & 7000 & 1,6958 & 5,3074 & 6,4868 & 8 \\
\hline 11,0 & 350 & 8555,5556 & 1,6290 & 6,7524 & 6,7524 & 8 \\
\hline
\end{tabular}

Tabel 5. Parameter analisis pada tanah non-kohesif

\begin{tabular}{ccccccc}
\hline $\mathrm{x}(\mathrm{m})$ & $\mathrm{n}_{\mathrm{h}}\left(\mathrm{kN} / \mathrm{m}^{3}\right)$ & $\mathrm{k}_{\mathrm{h}}\left(\mathrm{kN} / \mathrm{m}^{3}\right)$ & $\mathrm{T}$ & $\mathrm{Z}$ & Zmaks & $\mathrm{e} \mathrm{(m)}$ \\
\hline 4,5 & 1333,33333 & 133,3333 & 3,7445 & 1,20176 & 6,14233 & 0 \\
\hline 16 & 2000 & 56,2500 & 4,4500 & 3,59552 & 5,16856 & 0 \\
\hline 19 & 10666,6667 & 252,6316 & 3,2952 & 5,76592 & 6,97980 & 0 \\
\hline 23 & 33333,3333 & 652,1739 & 2,7259 & 8,43758 & 8,43758 & 0 \\
\hline
\end{tabular}

Sehingga dapat dihitung besar gaya lateral, putaran sudut, dan momen, gaya geser, reaksi tanah, dan defleksinya pada tiap kedalaman berdasarkan besar defleksi ijinnya dengan menggunakan persamaan (22) sampai dengan (26). Koefisien A dan B pada persamaan-persamaan tersebut dapat dilihat pada literatur Tomlinson dan Woodward (2015). Berikut hasil perhitungan yang didapat:

Tabel 6. Hasil analisis pada tanah kohesif

\begin{tabular}{cccccccc}
\hline $\mathrm{x}(\mathrm{m})$ & $\mathrm{H}(\mathrm{kN})$ & $\mathrm{M}(\mathrm{kNm})$ & $\mathrm{S}_{\mathrm{x}}(\mathrm{rad})$ & $\mathrm{M}_{\mathrm{x}}(\mathrm{kNm})$ & $\mathrm{V}_{\mathrm{x}}(\mathrm{kN})$ & $\mathrm{P}_{\mathrm{x}}(\mathrm{kN})$ & $\mathrm{y}_{\mathrm{x}}(\mathrm{m})$ \\
\hline 1,5 & 18,1085 & 144,8680 & $-0,0079$ & 163,2171 & 4,6263 & 18,6447 & 0,0120 \\
\hline 3,0 & 128,3655 & 1026,9237 & $-0,0162$ & 929,0003 & $-231,5944$ & 103,1058 & 0,0017 \\
\hline 4,5 & $-282,8736$ & $-2262,9891$ & 0,0069 & $-841,2534$ & 591,9942 & 130,9501 & $-0,0008$ \\
\hline 6,0 & $-283,1850$ & $-2265,4803$ & $-0,0048$ & $-89,4439$ & 269,7421 & 205,9677 & $-0,0008$ \\
\hline 7,5 & $-1763,9933$ & $-14111,9464$ & $-0,0308$ & 3574,5224 & $-112,3989$ & 428,7162 & $-0,0001$ \\
\hline 9,0 & $-3282,4333$ & $-26259,4663$ & $-0,0550$ & 739,9796 & $-807,0955$ & $-2379,7546$ & $-0,0001$ \\
\hline 11,0 & $-3654,4529$ & $-29235,6233$ & $-0,0584$ & $-641,5916$ & $-933,8692$ & $-2866,3110$ & $-0,0001$ \\
\hline
\end{tabular}

Tabel 7. Hasil analisis pada tanah non-kohesif

\begin{tabular}{cccccccc}
\hline $\mathrm{x}(\mathrm{m})$ & $\mathrm{H}(\mathrm{kN})$ & $\mathrm{M}(\mathrm{kNm})$ & $\mathrm{S}_{\mathrm{x}}(\mathrm{rad})$ & $\mathrm{M}_{\mathrm{x}}(\mathrm{kNm})$ & $\mathrm{V}_{\mathrm{x}}(\mathrm{kN})$ & $\mathrm{P}_{\mathrm{x}}(\mathrm{kN})$ & $\mathrm{y}_{\mathrm{x}}(\mathrm{m})$ \\
\hline 4,5 & 29,9122 & 0 & $-0,0048$ & 84,0048 & 4,4868 & 6,7900 & 0,0120 \\
\hline 16 & $-133,6656$ & 0 & $-0,0007$ & $-29,7404$ & 26,7331 & 7,5093 & $-0,0027$ \\
\hline 19 & $-658,3678$ & 0 & $-0,0018$ & 32,5420 & $-6,5837$ & $-9,9897$ & $-0,0005$ \\
\hline 23 & $-1163,0385$ & 0 & $-0,0022$ & 47,5549 & $-11,6304$ & $-21,3331$ & $-0,0003$ \\
\hline
\end{tabular}

\section{Analisis dengan Metode Beda Hingga (Finite-Difference Method)}

Analisis yang dilakukan dengan program metode beda hingga menggunakan Force FORTRAN 2.0 dimulai dengan memasukkan data: bentuk fondasi tiang, ukuran fondasi tiang, mutu bahan, panjang fondasi tiang, modulus subgrade tanah, dan jumlah elemen fondasi tiang. Pada tanah kohesif, jumlah elemen yang digunakan adalah delapan, sedangkan pada tanah non-kohesif jumlah elemennya adalah lima. Hasil output perhitungan program berupa nilai momen pada tiap elemen, defleksi pada tiap elemen, dan besar gaya lateral fondasi tiang. Berikut hasil perhitungan yang didapat: 
Studi Daya Dukung Lateral Fondasi Tiang Free-Head

Lilya Menggunakan Program Buatan Berbahasa Force FORTRAN 2.0

Tabel 8. Hasil analisis dengan program pada tanah kohesif

\begin{tabular}{ccc}
\hline Elemen & Momen $(\mathrm{kNm})$ & Defleksi $(\mathrm{m})$ \\
\hline 1 & 161,0547 & 0,0120000 \\
\hline 2 & 458,8188 & 0,0004981 \\
\hline 3 & 143,4966 & 0 \\
\hline 4 & $-484,0142$ & $-0,0001563$ \\
\hline 5 & $-137,5455$ & $-0,0001448$ \\
\hline 6 & 100,9212 & $-0,0000529$ \\
\hline 7 & 251,2501 & 0 \\
\hline 8 & 0 & 0 \\
\hline \multicolumn{2}{c}{ Gaya Lateral $(\mathrm{kN})$} & 20,1318 \\
\hline
\end{tabular}

Tabel 9. Hasil analisis dengan program pada tanah non-kohesif

\begin{tabular}{ccc}
\hline Elemen & Momen $(\mathrm{kNm})$ & Defleksi $(\mathrm{m})$ \\
\hline 1 & 80,8040 & 0,0120 \\
\hline 2 & 567,4660 & 0,0012 \\
\hline 3 & $-1661,4905$ & 0 \\
\hline 4 & $-1200,9755$ & 0,0001 \\
\hline 5 & 0 & 0 \\
\hline \multicolumn{2}{r}{ Gaya Lateral $(\mathrm{kN})$} & 17,5661 \\
\hline
\end{tabular}

\section{Perbandingan Hasil antara 3 Metode Perhitungan}

Berdasarkan perhitungan maka didapatkan hasil:

Tabel 10. Hasil analisis dengan 3 metode perhitungan pada tanah kohesif

\begin{tabular}{ccccccc} 
& \multicolumn{3}{c}{ Metode Broms } & \multicolumn{2}{c}{ Metode Matlock \& Reese } & \multicolumn{2}{c}{ Finite-Difference Method } \\
\hline Gaya Lateral $(\mathrm{H})$ & 13,14 & $\mathrm{kN}$ & 18,1085 & $\mathrm{kN}$ & 20,1318 & $\mathrm{kN}$ \\
\hline Momen $(\mathrm{M})$ & 113,9893 & $\mathrm{kNm}$ & 144,8680 & $\mathrm{kNm}$ & 161,0547 & $\mathrm{kNm}$ \\
\hline
\end{tabular}

Tabel 11. Hasil analisis dengan 3 metode perhitungan pada tanah non-kohesif

\begin{tabular}{ccccccc} 
& \multicolumn{3}{c}{ Metode Broms } & \multicolumn{2}{c}{ Metode Matlock \& Reese } & \multicolumn{3}{c}{ Finite-Difference Method } \\
\hline Gaya Lateral $(\mathrm{H})$ & 37,2133 & $\mathrm{kN}$ & 29,9122 & $\mathrm{kN}$ & 17,5661 & $\mathrm{kN}$ \\
\hline Momen $(\mathrm{M})$ & 149,9958 & $\mathrm{kNm}$ & 84,0048 & $\mathrm{kNm}$ & 80,8040 & $\mathrm{kNm}$ \\
\hline
\end{tabular}

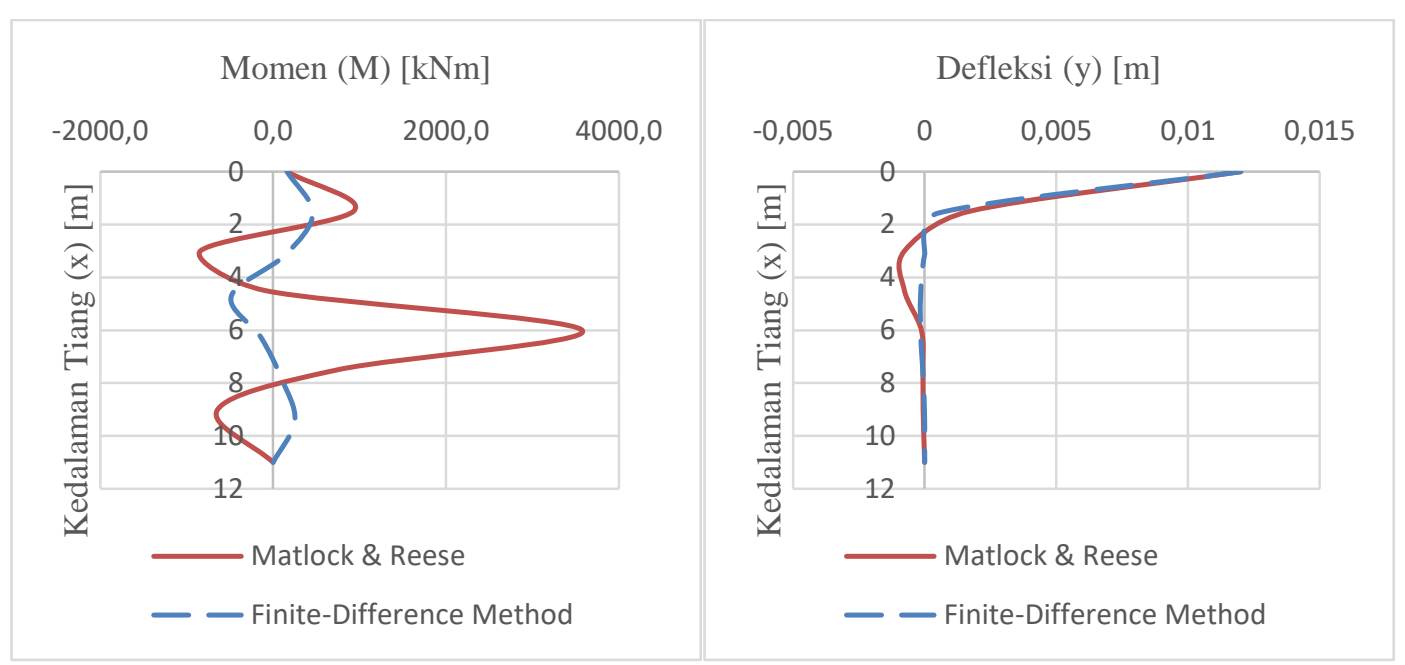

Gambar 5. Grafik Perbandingan Momen dan Defleksi Berdasarkan Metode Matlock \& Reese dan FiniteDifference Method pada Tanah Kohesif 


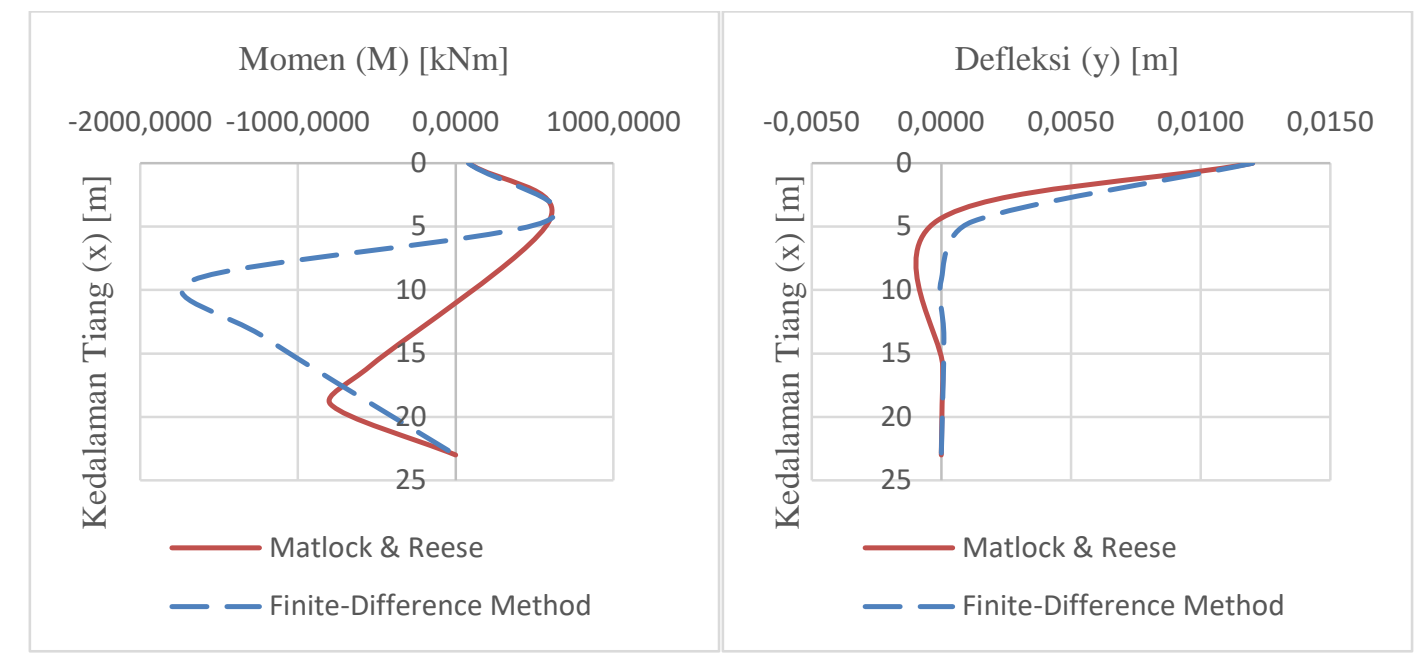

Gambar 6. Grafik Perbandingan Momen dan Defleksi Berdasarkan Metode Matlock \& Reese dan FiniteDifference Method pada Tanah Non-Kohesif

Perbedaan hasil analisis antara 3 metode ini karena parameter tanah yang digunakan dalam analisis berbeda yaitu pada metode Broms dan finite-difference method digunakan nilai rata-rata, sedangkan pada metode Matlock \& Reese digunakan nilai parameter sesuai dengan data pada tiap lapisan tanahnya. Berikut ini perbandingan hasil analisis jika pada metode Matlock \& Reese menggunakan nilai parameter yang sama dengan finite-difference method.

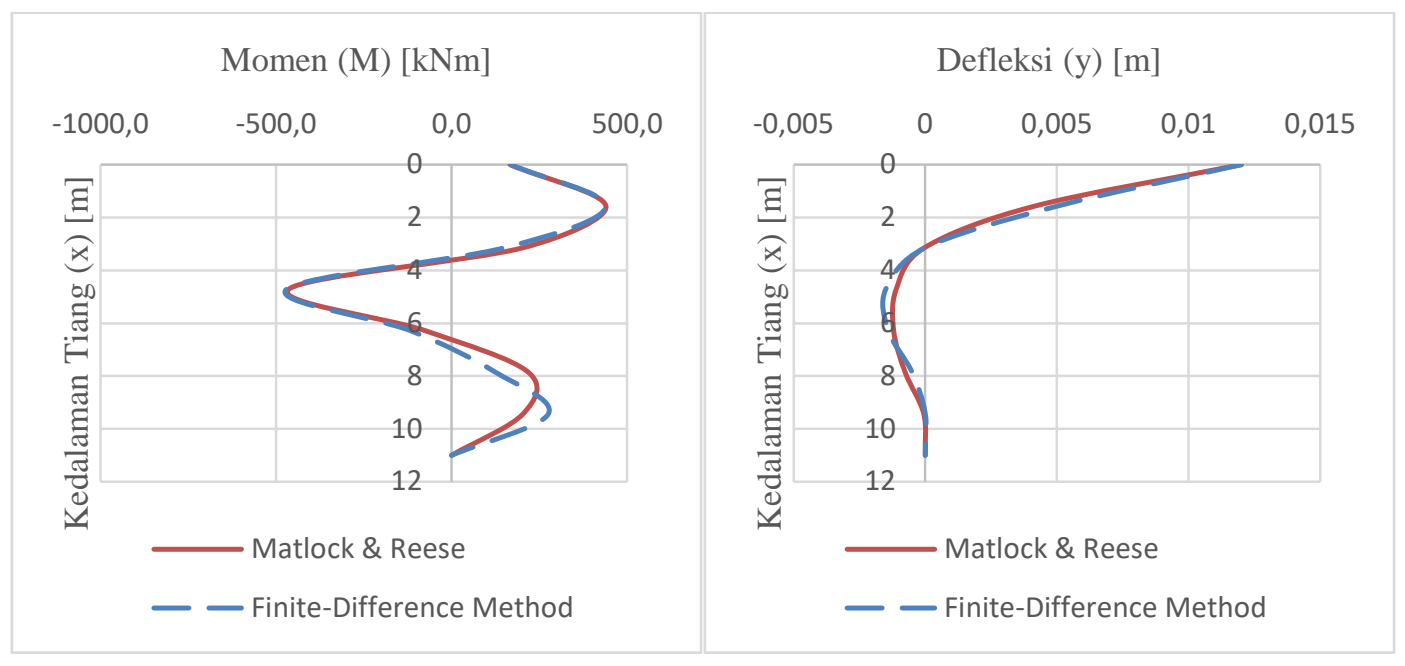

Gambar 7. Grafik Perbandingan Momen dan Defleksi Berdasarkan Metode Matlock \& Reese dan FiniteDifference Method dengan Nilai Parameter yang Sama pada Tanah Kohesif 


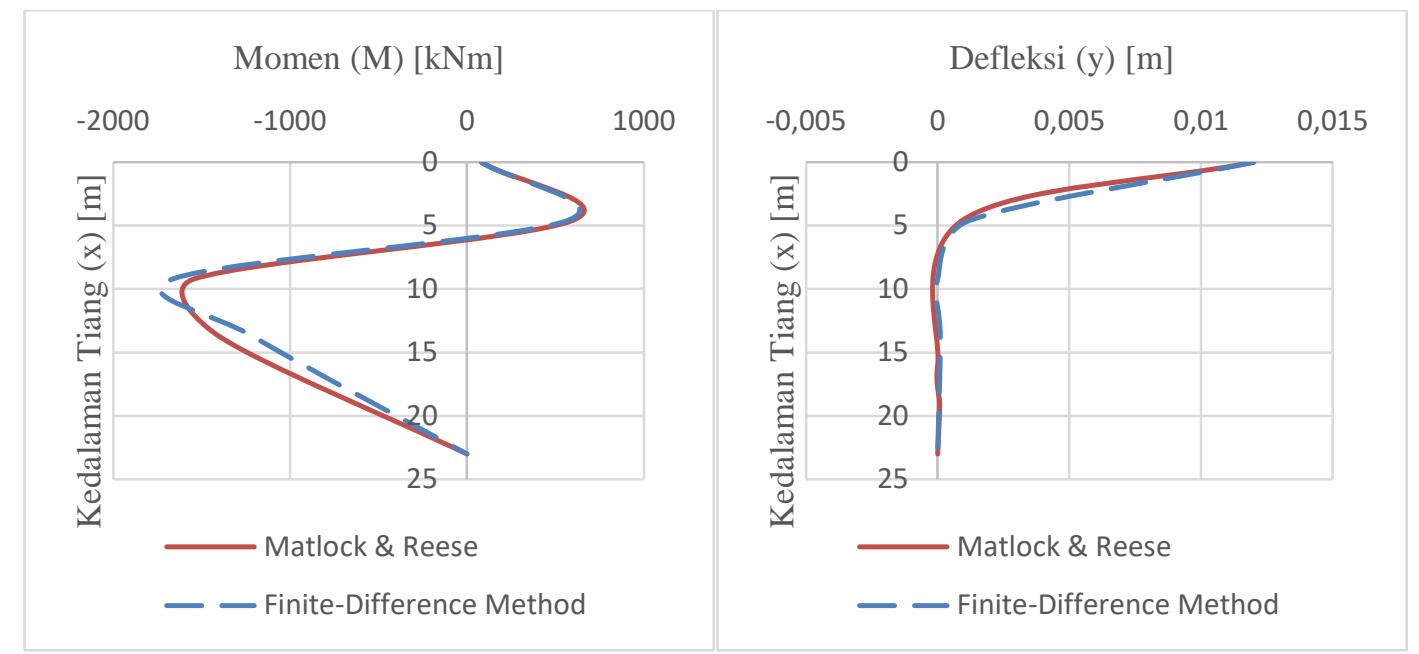

Gambar 8. Grafik Perbandingan Momen dan Defleksi Berdasarkan Metode Matlock \& Reese dan FiniteDifference Method dengan Nilai Parameter yang Sama pada Tanah Non-Kohesif

\section{KESIMPULAN}

Berdasarkan hasil analisis yang telah dilakukan, beberapa kesimpulan yang dapat diambil antara lain:

1. Hasil analisis dengan metode Matlock \& Reese merupakan hasil yang paling teliti di antara ketiga metode perhitungan karena parameter tanah yang digunakan sesuai dengan data pada tiap lapisan tanah sehingga metode ini dijadikan acuan untuk metode perhitungan lainnya.

2. Hasil analisis dengan metode Broms merupakan hasil yang paling tidak teliti karena parameter tanah yang digunakan merupakan nilai rata-rata.

3. Hasil analisis dengan finite-difference method merupakan hasil yang paling mendekati dengan hasil metode Matlock \& Reese walaupun parameter tanah yang digunakan merupakan nilai rata-rata karena ketelitian metode ini dipengaruhi oleh jumlah elemen yang dibagi.

4. Perbedaan hasil ketiga metode perhitungan dipengaruhi oleh spesifikasi parameter tanah yang digunakan dalam analisis.

\section{SARAN}

Berdasarkan hasil analisis yang telah dilakukan, saran yang dapat disampaikan yaitu pengembangan program yang telah dibuat dengan Force FORTRAN 2.0 untuk analisis pada tanah selain tanah yang bersifat homogen dan nilai parameter-parameter yang berbeda pada tiap-tiap lapisan tanah.

\section{DAFTAR PUSTAKA}

Napitupulu, E.D.S., dan Iskandar, R. (2013). Analisis Kapasitas Daya Dukung Pondasi Tiang Pancang Dengan Menggunakan Metode Analitis dan Elemen Hingga. Jurnal Teknik Sipil USU Vol. 2. No. 2

Sujatmiko, A.F. (2011). Simulasi Respon Pondasi Tiang Pancang Akibat Pembebanan Lateral Menggunakan Metode Beda Hingga. Media Teknik Sipil. Vol. 9. No. 2, 96-101

Tomlinson, M., and Woodward, J. (2015). Pile Design and Construction Practice $6^{\text {th }}$ ed. CRC Press Taylor \& Francis Group A Spon Press Book, London, New York 